\title{
FACTORS ASSOCIATED WITH COMMUNITY HEALTH WORKER PERFORMANCE IN NORTH MUSI RAWAS DISTRICT, BENGKULU
}

\author{
Violita Siska Mutiara, Yulita Elvira Silviani \\ Diploma IV Midwifery, School of Health Polytechnic \\ Tri Mandiri Sakti, Bengkulu
}

\begin{abstract}
Background: Earlier studies concluded that community health workers did not consistently provide services that were likely to have substantial effects on health and that quality was usually unsatisfactory. This study aimed to analyze factors associated with community health worker performance.

Subject and Method: This was a cross sectional study conducted in North Musi Rawas District, Bengkulu. A sample of 89 community health worker were selected by exhaustive sampling. The dependent variable was community health worker performance. The independent variables were knowledge, age, and tenure. The data were collected by questionnaire and analyzed by a multiple logistic regression model.

Results: Work performance was associated with knowledge $(\mathrm{OR}=5.21 ; 95 \% \mathrm{CI}=$ 1.32 to $9.13 ; \mathrm{p}=0.001$ ), age (OR $3.115 ; 95 \% \mathrm{CI}=1.09$ to $1.32 ; \mathrm{p}=0.013$ ), and tenure (OR 2.112; 95\% CI=0.93 to 2.13; $\mathrm{p}=0.043$ ).

Conclusions: Work performance of community health workers is associated with knowledge, age, and tenure.

Keywords: performance, tenure, knowledge, age, community health worker

\section{Correspondence:}

Violita Siska Mutiara. Diploma IV Midwifery, School of Health Polytechnic Tri Mandiri Sakti, Bengkulu. Jl. Hibrida Raya No.3 Sidomulyo, Bengkulu 38229.

E-mail: violitasiskamutiara@gmail.com. Mobile : 081173600o/08117301234.
\end{abstract}

